\title{
SEX IDENTIFICATION FROM RADIOLOGIC ANTHROPOMETRY OF SACRAL AND FIFTH LUMBAR VERTEBRAL MEASUREMENTS
}

\author{
Riham F. Hussein*, Dina A. Shokry*, Manal M. Ismail*, Manar H. Abd-Elsatar** and \\ Samah F. Ibrahim* \\ *Forensic Medicine \&Clinical Toxicology Department, **Assistant Professor of Radio- \\ diagnosis, faculty of medicine- Cairo University
}

\begin{abstract}
Forensic identification using new anthropological standards were developed to be applied to a specific population. Bone Computed Tomography (CT) reconstruction images have been reported in this forensic field. This study aimed to assess the sexual dimorphism by measuring the upper end plate width of fifth lumbar vertebra as well as anteroposterior diameter, transverse diameter, perimeter, area of the first sacral vertebra and width of sacral ala using abdominal computed tomography in 200 adult Egyptians. All measurements showed significant difference in sex identification except the width of sacral ala.
\end{abstract}

Key words: sex, sacrum, fifth lumbar vertebra, computed tomography

\section{INTRODUCTION}

Sex identification of suspect is an essential task in forensic science that minimizes the search population of suspects (Wadhwa et al.; 2013). Many human body features have been used to estimate sex, some examples include foot print ratio, metatarsals, long bones of the arm, foot shape, femoral head, foot, shoe dimensions, patella, teeth, radial and ulnar bones (Wang et al.; 2008).

Sex determination can be conducted through two methods, morphologic and metric (Ogawa et al.; 2013). Metric method was preferred due to its easy repeatability, high accuracy, and no requirement for special skill (Akhlaghi et al.; 2012).

The lumbar vertebrae are the largest segments of the movable part of the vertebral column that can be distinguished by the absence of a foramen in the transverse process and by the absence of facets on the sides of the body (Moore and Dalley, 2006). The body of the first segment of the sacrum is the largest size while the succeeding ones diminish from above downward. Its form resembles that of a lumbar vertebra. Both L5 and S1 vertebrae can be used in sex determination (Ludwikowski et al.; 2002 and Zheng et al. 2012).

\section{AIM OF THE WORK}

This study is aiming to:

- Emphasize the role of pelvic bone, lumbar vertebral measurements in sex determination.

- Creating local identification standards for pelvis and fifth lumbar vertebra.

\section{METHODOLOGY}

The present study was performed on 200 adult Egyptian patients (109 males and 91 females), who presented to the Diagnostic and interventional 
Radiological Department, Faculty of Medicine, Cairo University for abdomino-pelvic multi-slice computerized tomography (MSCT).

The Ethics Committee of Faculty of Medicine, Cairo University approved this study, and all the patients included in the study signed an informed consent document. The following exclusion criteria were used to ensure normal bone evaluation: skeletal immaturity, fracture, pathological lesions such as congenital developmental dysplasia, metabolic bone diseases or surgery, tumors and osteoarthritis.

\section{Radiological CT technique:}

The fifth lumbar vertebra and the first sacral segment measurements were determined by means of three dimensional image processing on an independent work station after doing a new recon with $1.5 \mathrm{~mm}$ slice width; bone window and sharpness B70 for optimum visualization using the software program analyze (Syngo VB 42). The patient was laid down in the supine position and no contrast was needed.

In this work six measurements; were assessed, one for the fifth lumbar vertebra and five for the first sacral vertebra. According to Zech et al. (2012), all measurements were in $\mathrm{mm}$ except the area in $\mathrm{cm}^{2}$

1- Width of the upper end plate of the fifth lumbar vertebra (L5): the maximum distance between the most two lateral points Fig. (1-A).

\section{2- First Sacral vertebra (S1):}

a. Maximum transverse diameter (m.t.d): the maximum distance between the two most lateral points Fig. (1-B).

b. Antero-posterior diameter (a.p.d): the maximum distance between the two most anterior and posterior projecting points Fig. (1-B).

c. Area: calculated by the software analyzer Fig. (1-C).

d. Maximum transverse diameter between the sacral ala: the maximum distance between the farthest two points of the sacral ala Fig. (1-D).

e. Perimeter: Calculated from the equation $=2 \times \pi \times \sqrt{\frac{r 1^{2}+\mathrm{r} 2^{2}}{2}}$

Where $\pi$ : is Pi; approximately $3.14, \mathrm{r} 1$ is the m.t.d and $r 2$ is the a.p.d

\section{Data analysis}

The data was coded and entered using the statistical package SPSS version 15 . The data was summarized using descriptive statistics: mean, standard deviation, minimal and maximum values for quantitative variables and number and percentage for qualitative values. Statistical differences between groups were tested using independent sample $\mathrm{t}$ test for quantitative normally distributed variables. Discrimination between males and females was evaluated by Receiver Operating Characteristic (ROC) curve analysis. Logistic regression analysis was used to test for significant predictors of individual sex. p-values less than or equal to 0.05 were considered statistically significant. 


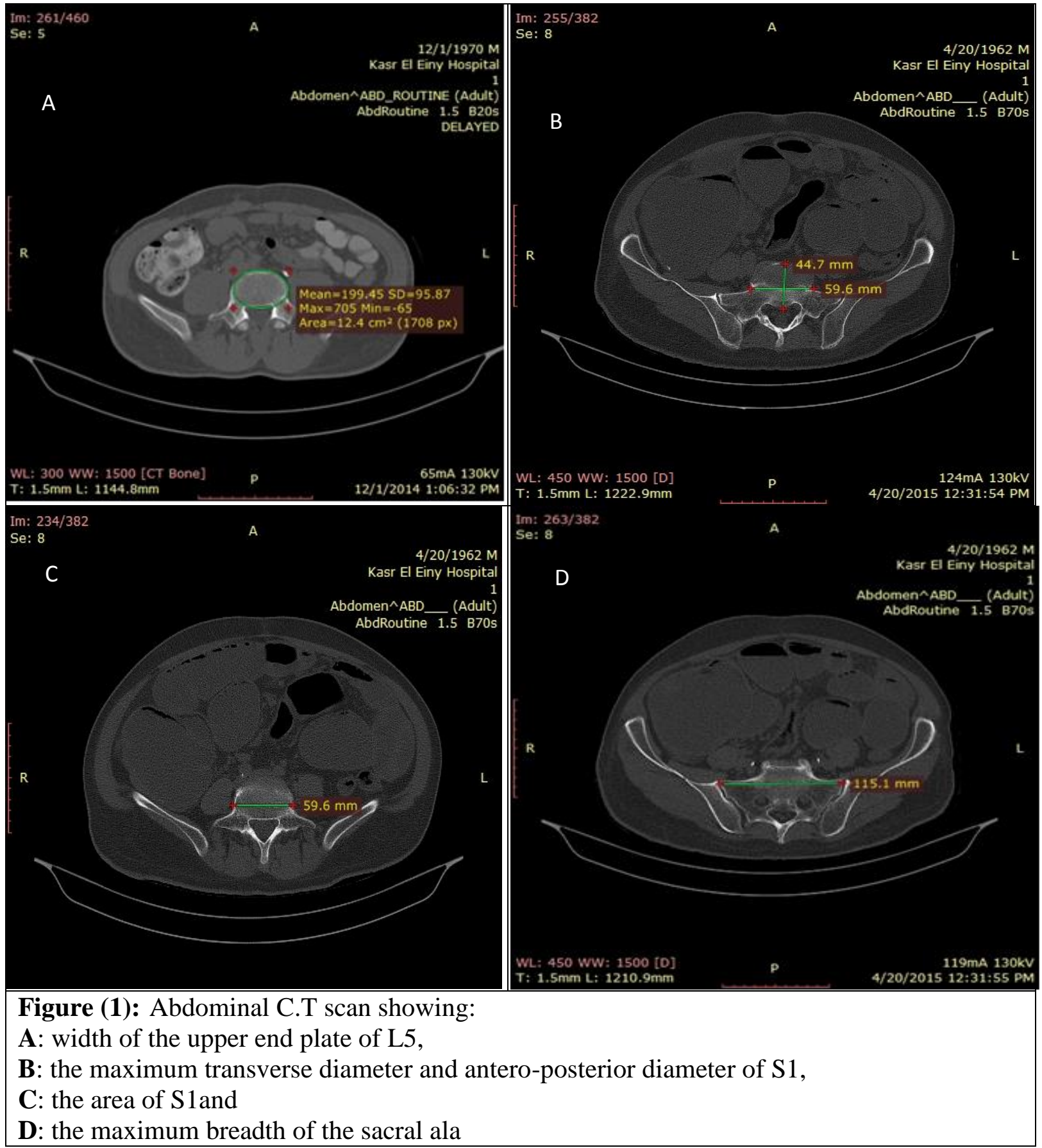

\section{RESULTS}

The sample in the present study consisted of 109 males $(54.5 \%)$ and 91 females $(45.5 \%)$ with mean ages of
$(46.4 \pm 11.9$ years $)$ and $(42.67 \pm 11.85$ years) respectively (Table 1).

Table (1): Demographic data of the studied subjects

\begin{tabular}{|c|c|c|c|}
\hline Sex & Number & $(\boldsymbol{\%})$ & Age (Mean \pm SD) \\
\hline Males & 109 & $(54.5 \%)$ & $46.4 \pm 11.9$ \\
\hline Females & 91 & $(45.5 \%)$ & $42.67 \pm 11.85$ \\
\hline Total cases & 200 & $(100 \%)$ & $44.7 \pm 12.02$ \\
\hline
\end{tabular}


A-CT measurements in the studied groups (Student ( $t$ ) test): of L5:

1- Width of the upper end plate

Regarding the width of the upper end plate of L5; females had statistically significant lower values compared to males; their values ranged between $41.6 \mathrm{~mm}$ and $66.9 \mathrm{~mm}$ with a mean of $51.57 \pm 4.59 \mathrm{~mm}\left(\mathrm{p}<0.001^{* *}\right)$ (Table 2).

Table (2): Student (t) test evaluating the difference in L5 measurements between the studied female and male groups

\begin{tabular}{|l|c|c|c|c|c|c|c|c|}
\hline & \multicolumn{3}{|c|}{ Female group } & \multicolumn{3}{c|}{ Male group } & \multirow{2}{\text{Student}}{$\begin{array}{c}\text { p-value } \\
\text { (t) test }\end{array}$} & \\
\cline { 2 - 7 } & Max. & Min. & Mean \pm SD & Max. & Min. & Mean \pm SD & & \\
\hline L5 & 66.9 & 41.6 & $51.57 \pm 4.5$ & 69.8 & 45.5 & $54.74 \pm 5.3$ & -4.4 & $<0.001 * *$ \\
\hline
\end{tabular}

$* *$ Significance was set at $\mathrm{p} \leq 0.05$

\section{2- First sacral vertebra:}

Descriptive statistics for the first sacral vertebra measurements were presented in (Table 3). It is apparent that all S1 measurements were lower in females than males. Four measurements; m.t.d, a.p.d, area and perimeter showed significant difference in sex identification $(\mathrm{p} \leq 0.05)$.

Table (3): Student ( $\mathrm{t}$ ) test evaluating the difference in five $\mathrm{S} 1$ measurements between the studied female and male groups

\begin{tabular}{|c|c|c|c|c|c|c|c|c|}
\hline & \multicolumn{3}{|c|}{ Female group } & \multicolumn{3}{c|}{ Male group } & \multirow{2}{*}{$\begin{array}{c}\text { Student (t) } \\
\text { test }\end{array}$} & p value \\
\cline { 2 - 8 } & Max. & Min. & Mean $\mathbf{\pm S D}$ & Max. & Min. & $\begin{array}{c}\text { Mean } \\
\pm \text { SD }\end{array}$ & & \\
\hline m.t.d & 61.4 & 39 & $51.71 \pm 5.1$ & 74.6 & 35.5 & $54.79 \pm 6.0$ & -3.8 & $<0.001^{* *}$ \\
\hline a.p.d & 59.2 & 30.6 & $40.57 \pm 5.5$ & 59.6 & 30.5 & $42.4 \pm 5.23$ & -2.4 & $<0.015^{* *}$ \\
\hline $\begin{array}{c}\text { Ala } \\
\text { breadth }\end{array}$ & 118.7 & 90.3 & $107.59 \pm 6.3$ & 127.1 & 76.2 & $108.3 \pm 7.6$ & -0.6 & $<0.504$ \\
\hline Area & 26.8 & 10.5 & $16.5 \pm 3.1$ & 31.8 & 9.9 & $18.2 \pm 3.63$ & -3.6 & $<0.001^{* *}$ \\
\hline Perimeter & 18.8 & 11.8 & $14.5 \pm 1.3$ & 20 & 11.1 & $15.3 \pm 1.6$ & -3.8 & $<0.001^{* *}$ \\
\hline
\end{tabular}

m.t.d (maximum transverse diameter of S1), a.p.d (the anteroposterior diameter of S1), ** Significance was set at $\mathbf{p} \leq \mathbf{0 . 0 5}$

\section{Receiver Operating}

Characteristic (ROC) curve:

Area under this curve measures the ability of the tested parameter to correctly discriminate between two groups (males \& females). Area under the ROC curve is divided into four zones; A(0.9-1:excellent), B (0.8- 0.89:good), C (0.7-0.79: fair), $\mathrm{D}(0.6-$ 0.69: poor) and $\mathrm{E}$ (0.5-0.59: failure). Regarding the Roc curve values in our study; all measurements were in the D zone except the breadth of the sacral ala was in E zone. (Table 4 and Fig. 2). 
Table (4): Area under the ROC curve for all studied measurements

\begin{tabular}{|c|c|c|c|c|}
\hline Variables & Area & Sig. & \multicolumn{2}{|c|}{ 95\% confidence interval } \\
\cline { 4 - 5 } & & & Lower bound & Upper bound \\
\hline L5 & 0.665 & $<0.001^{* *}$ & 0.591 & 0.740 \\
\hline a.p.d & 0.609 & $<0.008^{* *}$ & 0.530 & 0.687 \\
\hline m.t.d & 0.652 & $<0.001^{* *}$ & 0.576 & 0.727 \\
\hline Area & 0.648 & $<0.001^{* *}$ & 0.572 & 0.724 \\
\hline Perimeter & 0.657 & $<0.001^{* *}$ & 0.582 & 0.733 \\
\hline Ala breadth & 0.523 & 0.574 & 0.443 & 0.603 \\
\hline
\end{tabular}

** Significance was set at $\mathrm{p} \leq 0.05$

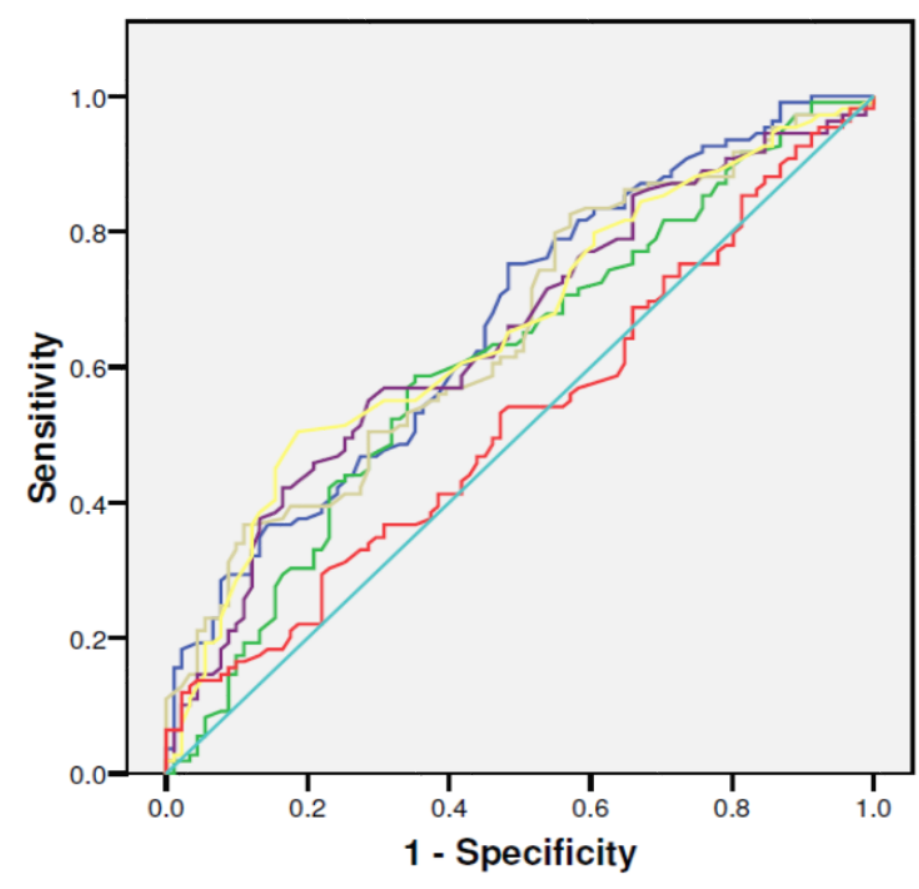

Fig. (2): ROC curve for all studied parameters

Moreover, cut off values, their specificity and sensitivity in correct sex classification for males and females using L5 and S1 measurements were represented in (Table 5). A subject is considered male if his measurements are above the mentioned values and vice versa.

Table (5): Cut off values, their sensitivity and specificity of measured parameters indicating male sex

\begin{tabular}{|c|c|c|c|}
\hline Measured parameters & Cut off value & Sensitivity & Specificity \\
\hline L5 & 51.1 & $71 \%$ & $52 \%$ \\
\hline a.p.d & 40.1 & $63 \%$ & $53 \%$ \\
\hline m.t.d & 52.4 & $62 \%$ & $52 \%$ \\
\hline Area & 16.5 & $66 \%$ & $52 \%$ \\
\hline Perimeter & 14.6 & $65 \%$ & $52 \%$ \\
\hline
\end{tabular}


In the logistic regression statistics using age, we found that the width of the upper end plate of L5 was the only significant variable determination (Table 6)

Table (6): Logistic Stepwise Regression Statistics depending on L5 as variable

\begin{tabular}{|c|c|c|c|c|}
\hline Step & B & \multirow{2}{*}{ Sig. } & \multicolumn{2}{|c|}{ 95\% confident interval } \\
\cline { 3 - 5 } & & & Lower & Upper \\
\hline L5 & 0.130 & $0.000^{* *}$ & 1.069 & 1.213 \\
\hline Constant & -6.7 & \multicolumn{3}{|l}{} \\
\hline
\end{tabular}

$* *$ Significance was set at $\mathbf{p} \leq \mathbf{0 . 0 5}$

The accuracy of L5 in sex determination was found to be 59.5\% (Table 7).

Table (7): The accuracy of the logistic regression using L5 analysis in sex prediction

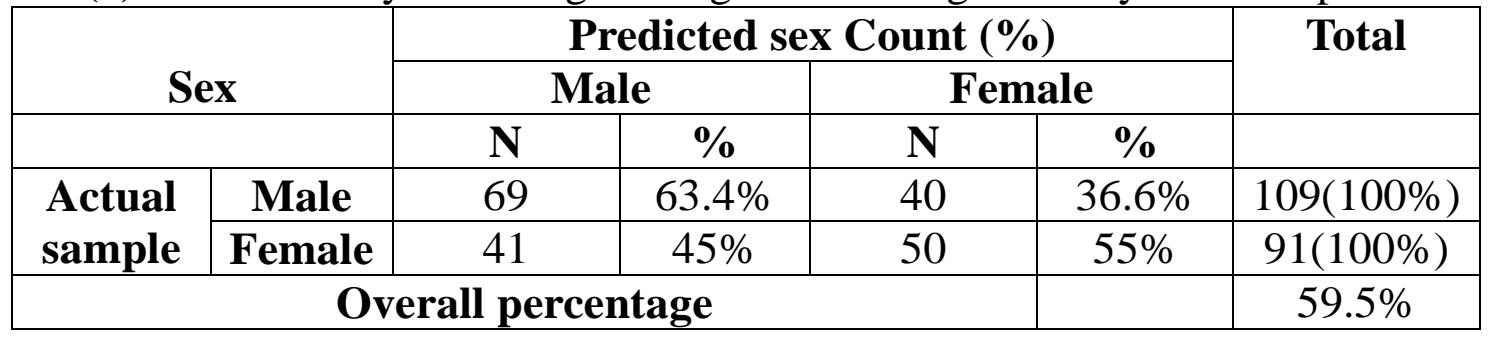

\section{DISCUSSION}

Human identification depending on radiological image technique analysis is a practice and a proper method in forensic science field (Franklin, 2010). Sex determination from skeleton remains is essential forensic step, as this helps in identification of missing person (Stavrianos et al.; 2009). Metric data of the S1 measurements, (a.p.d), (m.t.d), area, perimeter and ala breadth, and width of the upper end plate of L5 were used in this study. All measurements showed higher males values and statistically significant difference between male and female subjects $\left(p<0.05^{*}\right)$ except the sacral ala breadth.

The results of the present study matched with Steyn \& Iscan (2008), Benazzi et al. (2009), Zech et al. (2012) and Franklin et al. (2014), while it did not match with Steyn \& Patriquin (2009) who found a statistically significant difference between males and females regarding measurements of ala breadth. This may be due to different research method and population (Table 8). 
Table (8): Comparison of the present study with previously published studies regarding sex determination using S1 measurements

\begin{tabular}{|c|c|c|c|c|}
\hline Authors & $\begin{array}{l}\text { Population } \\
\text { (No) }\end{array}$ & $\begin{array}{l}\text { Research } \\
\text { method }\end{array}$ & Measured parameters & Accuracy \\
\hline Present study & $\begin{array}{l}\text { Egyptians } \\
(200)\end{array}$ & CT & $\begin{array}{l}\text { m.t.d, a.p.d, area, perimeter } \\
\text { and ala breadth }\end{array}$ & Perimeter (69.6\%) \\
\hline $\begin{array}{l}\text { Benazzi et al. } \\
(2009)\end{array}$ & Italian (114) & $\begin{array}{l}\text { Digital } \\
\text { camera }\end{array}$ & $\begin{array}{l}\text { m.t.d, area, perimeter and ala } \\
\text { breadth }\end{array}$ & Area $(86.9 \%)$ \\
\hline $\begin{array}{l}\text { Steyn } \quad \& \\
\text { Patriquin } \\
(2009)\end{array}$ & $\begin{array}{lr}\begin{array}{l}\text { South } \\
\text { (white }\end{array} & \begin{array}{r}\text { Africa } \\
\text { and }\end{array} \\
\text { black } & (399), \\
\text { and } & \text { Greeks } \\
(193) & \\
\end{array}$ & Bone & $\begin{array}{l}\text { ala breadth, pubic length, } \\
\text { ischial length, greater sciatic } \\
\text { notch breadth and greater } \\
\text { sciatic notch depth }\end{array}$ & $\begin{array}{l}\text { Ala breadth\& pubic } \\
\text { length in white, black } \\
\text { and Greeks }(80.3 \% \text {, } \\
85.6 \% \text { and } 82.6 \%)\end{array}$ \\
\hline $\begin{array}{l}\text { Zech et al. } \\
(2012)\end{array}$ & Swiss (95) & CT & $\begin{array}{l}\text { m.t.d, a.p.d, area, perimeter } \\
\text { and ala breadth }\end{array}$ & $\begin{array}{l}\text { Perimeter\& a.p.d } \\
(78.9 \%)\end{array}$ \\
\hline $\begin{array}{l}\text { Franklin et al. } \\
\text { (2014) }\end{array}$ & $\begin{array}{l}\text { Australian } \\
(400)\end{array}$ & CT & $\begin{array}{l}\text { m.t.d, a.p.d, pelvic inlet and } \\
\text { outlet }\end{array}$ & $\begin{array}{l}\text { Sacral data }(69 \%) \\
\text { All data }(100 \%)\end{array}$ \\
\hline $\begin{array}{l}\text { Steyn \& Iscan } \\
(2008)\end{array}$ & Greeks (192) & Bone & $\begin{array}{l}\text { m.t.d, a.p.d, pubic length, } \\
\text { ischial length, greater sciatic } \\
\text { notch (breadth\& depth) and } \\
\text { acetabular diameter }\end{array}$ & m.t.d\& a.p.d (60.9\%) \\
\hline
\end{tabular}

(No): number

By applying the ROC curve, we found that the most significant parameter in sex determination from $\mathrm{S} 1$ measurements is the "perimeter" parameter with an accuracy of about 69.6\%. The forward stepwise regression analysis of all parameters didn't show any significant improvement as it showed $68.8 \%$ prediction probability, while using the a.p.d showed $66 \%$ accuracy; the area showed $68 \%$ prediction probability, while the m.t.d showed $68.9 \%$ prediction probability accuracy.

Table (9): Comparison of the present study with previously published studies regarding sex determination using L5 measurement

\begin{tabular}{|l|l|l|l|l|}
\hline Authors & $\begin{array}{l}\text { Population } \\
\text { (No) }\end{array}$ & $\begin{array}{l}\text { Research } \\
\text { subjects }\end{array}$ & Measured parameters & Accuracy \\
\hline $\begin{array}{l}\text { Present } \\
\text { study }\end{array}$ & $\begin{array}{l}\text { Egyptians } \\
(200)\end{array}$ & CT & Width of upper end plate L5 & $\begin{array}{l}\text { Width of upper } \\
\text { end plate (60\%) }\end{array}$ \\
\hline $\begin{array}{l}\text { Zheng et al. } \\
\mathbf{( 2 0 1 2 )}\end{array}$ & $\begin{array}{l}\text { Chinese } \\
(210)\end{array}$ & CT & $\begin{array}{l}\text { Width of upper and middle end } \\
\text { plate. Moreover height of the left } \\
\text { pedicle. }\end{array}$ & $\begin{array}{l}\text { Width of upper } \\
\text { end plate (85\%) } \\
\text { All data (89\%) }\end{array}$ \\
\hline $\begin{array}{l}\text { Tan et al. } \\
\mathbf{( 2 0 0 2 )}\end{array}$ & Asian (60) & $\begin{array}{l}\text { Bone } \\
\text { measuerments }\end{array}$ & $\begin{array}{l}\text { Width, area and depth of both } \\
\text { upper and lower end plate. } \\
\text { Moreover spinal canal and pedicle } \\
\text { measurements. }\end{array}$ & \\
\hline
\end{tabular}


The present findings were on the same line with those of Tan et al. (2002) and Zheng et al. (2012), They concluded that, lumbar vertebrae could be used in determination of sex among the studied

groups. Moreover the accuracy rate in Zheng et al. (2012) study is $25 \%$ higher thanthe precent in the present work. This difference may be due to different sample type and size.

\section{CONCLUSION}

CT scan was a valuable method in measuring the selected pelvic sacral dimensions (maximum transverse diameter, antero- posterior diameter, area, perimeter, length of sacral ala) as well as fifth lumbar vertebral dimension (upper end plate width). The most accurate dimension in estimating sex is the perimeter of S1 with accuracy $69.6 \%$ then the upper end plate width of L5with accuracy $60 \%$

\section{RECOMMENDATIONS}

1- More researches are needed to coup with the increasing numbers of unidentified skeletons all over the world.

2- More parameters should be tested to increase the accuracy of sex determination

3- Logistic regression is population specific; that need more researches on different populations.

\section{REFERENCES}

Akhlaghi, M., Moradi, B. and Hajibeygi, M. (2012): Sex determination using anthropometric dimensions of the clavicle in
Iranian population, J. Forensic Legal Med.; 19: 381-385.

Benazzi, S.; Maestri, C.; Parisini, S. et al. (2009): Sex Assessment from the Sacral Base by Means of Image Processing, J. Forensic Sci.; 54: 25.

Franklin, D. (2010): Forensic age estimation in human skeletal remains: current concepts and future directions. Leg Med; 12(1):1-7.

Franklin, D.; Cardini, A.; Flavel, A. et al. (2014): Morphometric analysis of pelvic sexual dimorphism in a contemporary Western Australian population, Int. J. Legal Med.; 126 (4): 549-58.

Ludwikowski, B.; Oesch-Hayward, I. and Fritsch, H. (2002): Rectovaginal fascia: an important structure in pelvic visceral surgery?

Moore, K. and Dalley, A. (2006): pelvis in: Clinically Oriented Anatomy, Moore, K. and Dalley, A. (Eds.), $5^{\text {th }}$ edition. Baltimore, Med, Lippincott Williams \& Wilkins. PP: 987-994.

Ogawa, Y., Imaizumi, K., Miyasaka, S.; et al.; (2013): Discriminant functions for sex estimation of modern Japanese skulls. J. Forensic Legal Med.; 20: 234-238.

Stavrianos, C.; Stavrianos, I.; Dietrich, E. et al. (2009): Method of human identification in forensic dentistry: J Forensic Sci; 4(1).

Steyn, M. A. and Iscan, M. Y. (2008): Metric sex determination from the pelvis in modern Greeks, Forensic Sci. Int.; 179: 86.e1-86.e6.

Steyn, M. and Patriquin, M.L. (2009): Osteometric sex 
determination from the pelvisdoes population specificity matter? Forensic Sci. Int.; 191: 113.e1113.e5.

Tan, S.H.; Teo, E.C. and Chua, H.C. (2002): Quantitative threedimensional anatomy of lumbar vertebrae in Singaporean Asians, Eur. Spine J.; 11: 152-158.

Wadhwa, R., Kaur, M. and Singh, K. (2013): Age and Gender Determination from Finger Prints using RVA and DCT Coefficients., IOSR J. Eng. (IOSRJEN); 3(8): 59.
Wang, J.-F., Lin, C.-L., Chang, Y.H.; et al. (2008): Gender Determination using Fingertip Features', Internet J. Med. Update; 3(2): 22-28.

Zech, W.; Hatch, G.; Siegenthaler, L. et al. (2012): Sex determination from os sacrum by postmortem CT. Forensic Sci. Int.; 221: 39-43.

Zheng, W.; Cheng, F.; Cheng, K. et al. (2012): Sex assessment using measurements of the first lumbar vertebra. Forensic Sci. Int.; 219: 285e1-e5. 


\section{الماخص العربي}

تحديد الهوية الجنسية باستخدام الاثعة المقطعية عن طريث استخدام معايير

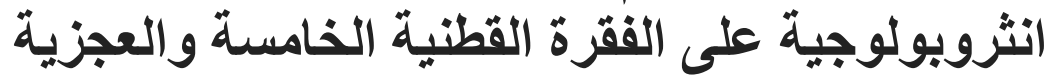

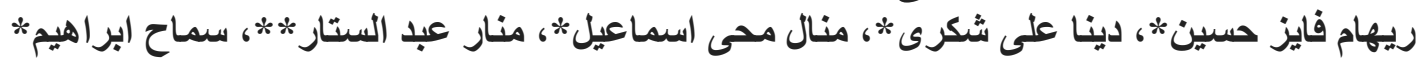

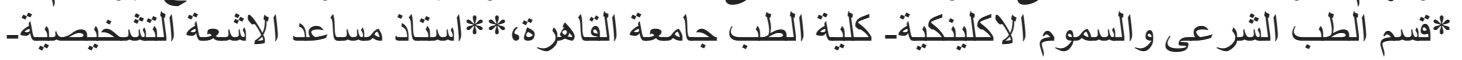

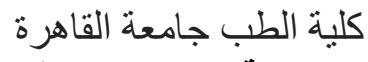

تم تحديد الهوية باستخدام معايير أنثروبولوجية جليدة ليتم تطبيقها على مجموعة سكانية محددة

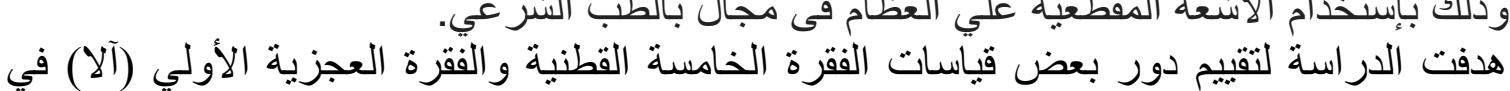

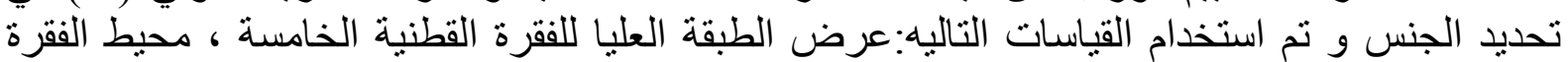

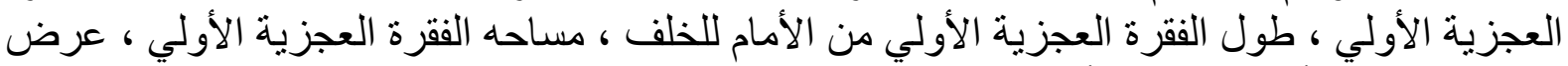

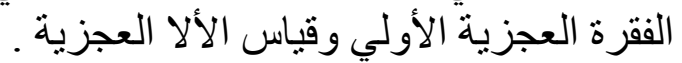
تم أخذ القياسات بو اسطه الأشعه المقطعيه لعدد . . ب شخص من قسم الأشعه بالقصر العيني وقد وقع

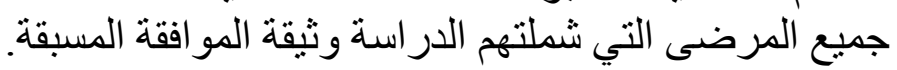
وكانت كل القياسات ذات دلاله احصائيه ما عدا قياس الالا العجزيه 